\title{
Population Density of the Striped Mealybug Ferrisia virgata (Ckll.) (Hemiptera: Pseudococcidae) on the Ornamental Corn Shrubs, Dracena fragrans in Relation to Biotic and Abiotic Factors in Al-Zohria Gardens, Cairo, Egypt Ata, T. E. ${ }^{1}$; S. M. El-Awady ${ }^{2}$; A. S. El-Khouly ${ }^{2}$ and M. M. Metwally ${ }^{2}$ ${ }^{1}$ Dep. of Economic Entomology Fac. of Agric. Damietta University Cairo, Egypt. ${ }^{2}$ Dep. of Plant Protection. Fac. of Agric. Al-Azhar University. Cairo. Egypt.
}

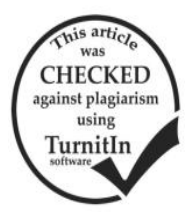

\section{ABSTRACT}

The striped mealybug Ferrisia virgata (Ckll.) (Hemiptera: Pseudococidae) attacks many host plants including shrubs and trees in Egypt. The aim of this work is to study the population densities of striped mealybug and the effect of biotic and abiotic factors on the insect population and the preferable direction for the insect stages on ornamental corn shrubs, Dracena fragrans in Al-Zohria gardens at Cairo during two successive years (2014-2015) (2015-2016). The results showed that the highest number of $F$. virgata insects occurred during Sep. in the first year, while it occurred during Nov. in the second year, with average ( 93.5 and 42.1 insect / sample) in the first and second years respectively. The general mean number of $F$. virgata has of 24.7 during the first year while it was 16.6 in the second year of investigation. The results showed that the insect population was highest in autumn with average (64.3 and 44.6 insect/ sample) in the first and second year respectively, whereas the lowest mean was in spring ( 2.7 and $1.5 \mathrm{insect} / \mathrm{sample}$ ) during the two successive years. The data revealed insignificant relation between daily maximum, range and minimum of temperature and natural enemies on population activity. On the other hand the relation between the relative humidity and the population activities was highly significant positive correlation in both two years. In respect to preferable direction, results showed that the north-eastern direction was the preferable direction for the population activity in the both years of the study.

Keywords: the striped mealybug, population density, ornamental corn shrubs, Biotic and Abiotic factors, Egypt.

\section{INTRODUCTION}

Ornamental plants play an important role in the national economy as a large amount of these plants are frequently exported to foreign countries. Trees, shrubs and cut flowers form a large part of ornamental plants. Insect pests are regarded as one of the important injurious factors responsible for deterioration of ornamental plants in Egypt.

Many species of mealybugs attack agricultural, ornamental and greenhouse plants all over the world. During feeding they consume so much plant sap, and then excrete a lot of sugary liquid, called honeydew. These later encouraged the growth of sooty molds, which inhibit photosynthesis and reduce the aesthetic value of such plants. Some species of mealy bugs lay eggs and others give birth to living young ones; when eggs are laid they are placed in loose cottony wax (Beardsley 1977).

The striped mealybug Ferrisia virgata (Ckll.), a major pest of several vegetables and ornamental plants was investigated in the Philippines. It was most abundant from February to May and observed feeding on 76 species of plants belonging to 33 families (Lapis 1970). In Egypt (Nada 1987) surveyed insect pests attacking ornamental plants in greenhouses. A total of 25 insect species belonging to 20 genera and 5 families were identified. These included the pseudococcids $F$. virgata, Planococcus citri and Pseudococcus longispinus. Most species attacked more than one host plant.

The degree of infestation varied considerably with time of year. Biotic and abiotic factors, as well as the substrate they feed influence its population (Gaaboub et al., 1979 and Bazarov, 1988). Temperature has profound effects on insect life history parameters such as development, survival, and reproduction. The response of insects to temperature can be important in predicting the potential geographical range of a species and in developing phonological models to predict population dynamics and the timing of various stages for planning control or survey programs (Keena, 2006). There for the aim of this study shed light on the infestation of striped mealybug on the ornamental corn shrubs and the effects of the weather factors and natural enemies on the insect population and the relationship between the insect and these factors and the preferable direction for the insect.

\section{MATERIALS AND METHODS}

\section{Study area:}

The experiment was carried out for survey and inspection of plant species infested with the striped mealybug Ferrisia virgata during the period extended from March 2014 till February 2016 in Al-zohria botanic gardens at Cairo Governorate. To study the infestation level and development of the striped mealybug $F$. virgata population on the ornamental corn shrubs, Dracena fragrans, varnish-leaf shrubs. The shrubs (20 shrubs were chosen at random in each direction of garden) are similar in size and didn't receive any pesticides treatments during the period of study.

Experiment procedure:

Population densities of mealy bug and its natural enemies:

The numbers of each insect stage (eggs, nymphs $\left(1^{\text {st }}, 2^{\text {nd }}, 3^{\text {rd }}, 4^{\text {th }}\right.$ instar $)$ adult male and females $)$ and attendant natural enemies were carefully observed, counted and recorded weekly on five plant leaves (one leaf per plant chosen by random for each direction east, west, south, north and center) of inspected plants. The leaves were chosen randomly from the cultivated plants. Of each direction selected plant leaves were collected and packed in labeled plastic cans then transported immediately to the laboratory for classifying and counting the existing individuals of detected species using a stereoscopic binocular microscope. The upper and lower surfaces of the leaves were carefully examined. The numbers of each insect stage per leaf was examined and recorded, with the same manner the natural enemies observed and recorded.

Effect of biotic and abiotic factors on the insect population

Weather factors (daily maximum, daily range, daily minimum temperature and daily mean of relative humidity) were obtained for Cairo area during the period of investigation from the internet (www.wunderground.com). 
The effect on insect population changes was assumed to be the reflection of the influence of the weather factors prevailing during the past seven days before the date of inspection and the natural enemies in the day of inspection.

The relationships between biotic \& abiotic factors and population activity of $F$. virgata stages were studied.

Statistical analysis of the obtained data was followed using ANOVA and partial regression procedures in SAS (SAS, 1988). Mean separation was conducted by using the Duncan multiple range test (Duncan, 1950).

The preferable direction for the insect stages:

To detect the effect of the cardinal directions on the distribution of $F$. virgata mathematically, the following formula was used

$\mathbf{H}=\sqrt{ } \mathbf{F 1}^{2}+\mathbf{F 2}^{2}+$ 2F1 F2 Cos Q, (Mahmoud, 1981)

$\mathbf{H}=$ Power summation

F1 = The population on the (E) minus the population on the (W) if former is higher, and reversed it if the later is higher.

$F 2=$ The population on the (N) minus the population on the (S) if the former is higher, and the reverse is applied if the population on the south is higher.

The figure obtained represents the tangent, the corresponding values of which were obtained from the mathematical.

$$
\begin{gathered}
\mathrm{F} 1=\mathrm{E}-\mathrm{W} \quad \mathrm{F} 2=\mathrm{N}-\mathrm{S} \quad \tan \mathrm{Q}=\mathrm{F} 2 / \mathrm{F} 1 \\
\text { RESULTS AND DISCUSSION }
\end{gathered}
$$

Population fluctuation of the striped mealybug $F$. virgata on the ornamental corn shrubs:

The obtained results presented in Table (1) showed that Ferrisia virgata (Ckll.) infestation during the first year of investigation 2014/2015, it was started in March 2014 with little number of insects 0.7 individuals/ sample. The insect population was fluctuated during about three months, April, May and Jun thin it was increased during July with mean number of insects 13.0 individuals/ sample. After that the number of insects has increased gradually to reach the highest peak during Sep. with mean number of insects 93.5 individuals/ sample. Then the population decreased gradually until the end of Feb.

Table 1. Monthly average numbers of $F$. vergata stages per 5 leaves of the ornamental corn shrubs during 2014 /15 year at Al-Zohrya GardenCairo Governorate.

\begin{tabular}{lcccccccc}
\hline & \multicolumn{3}{c}{ Immature Stages / 5 leaves } & \multicolumn{2}{c}{ Adult } & \\
\cline { 2 - 7 } Date & Eggs & $\mathbf{1}^{\text {st }}$ & 2nd & 3rd & 4th & $\begin{array}{c}\text { Femal } \\
\text { e }\end{array}$ & Male & Total \\
\hline Mar. & 0.1 & 0.0 & 0.0 & 0.0 & 0.0 & 0.6 & 0.0 & 0.7 \\
Apr. & 0.3 & 1.0 & 0.0 & 0.1 & 0.0 & 1.1 & 0.0 & 2.5 \\
May & 0.5 & 3.1 & 0.8 & 0.0 & 0.0 & 0.8 & 0.0 & 5.2 \\
Jun & 0.1 & 1.1 & 0.3 & 1.1 & 0.0 & 1.3 & 0.1 & 3.9 \\
Jul & 0.7 & 5.7 & 2.7 & 1.0 & 0.1 & 2.7 & 0.2 & 13.0 \\
Aug. & 1.8 & 18.7 & 8.2 & 6.5 & 0.7 & 4.5 & 0.3 & 40.5 \\
Sep. & 3.0 & 47.9 & 22.7 & 12.0 & 1.1 & 6.2 & 0.6 & 93.5 \\
Oct. & 0.6 & 17.7 & 9.9 & 4.1 & 0.3 & 7.5 & 0.2 & 40.1 \\
Nov. & 1.6 & 37.7 & 18.2 & 8.1 & 1.7 & 6.5 & 0.6 & 74.1 \\
Dec. & 0.6 & 7.0 & 2.0 & 2.5 & 0.2 & 2.5 & 0.0 & 14.7 \\
Jan. & 0.1 & 2.9 & 0.8 & 0.5 & 0.0 & 2.0 & 0.0 & 6.2 \\
Feb. & 0.0 & 0.2 & 0.1 & 0.1 & 0.0 & 1.6 & 0.0 & 1.9 \\
\hline Total & 9.2 & 142.8 & 65.5 & 35.7 & 3.9 & 37.2 & 1.8 & 296.0 \\
\hline \multirow{2}{*}{ Mean } & $0.8 \pm$ & $11.9 \pm$ & $5.5 \pm$ & $3.0 \pm$ & $0.3 \pm$ & $3.1 \pm$ & $0.2 \pm$ & $24.7 \pm$ \\
& 0.9 & 15.9 & 7.8 & 3.9 & 0.5 & 2.4 & 0.2 & 31.1 \\
\hline
\end{tabular}

The population fluctuation of $F$. virgata during second year of investigation 2015/16 was presented in Table (2), which revealed that $F$. virgata infestation started in March 2015 with average number of insects 0.8 individuals/ sample. Few numbers of insects was recorded during the two successive months, April and May thin it was increased during June with average number of insects 6.6 individuals/ sample. After that the number of insects has increased gradually to reach the highest peak during Nov. with mean number of insects 42.1 individuals/ sample. Then the population decreased until the end of Feb.

Table 2. Monthly average number of F.vergata stages per 5 leaves of the ornamental corn shrubs during 2015 /16 year at Al-Zohrya GardenCairo Governorate.

\begin{tabular}{lccccccccc}
\hline \multirow{2}{*}{ Date } & \multicolumn{1}{c}{ Immature } & Stages / 5 leaves & \multicolumn{3}{c}{ Adult } & \multirow{2}{*}{ Total } \\
\cline { 2 - 9 } & Eggs & 1st & 2nd & 3rd & 4th & Female & Male & \\
\hline Mar. & 0.0 & 0.0 & 0.0 & 0.0 & 0.0 & 0.8 & 0.0 & 0.8 \\
Apr. & 0.0 & 0.1 & 0.0 & 0.0 & 0.0 & 0.5 & 0.0 & 0.6 \\
May & 0.0 & 0.3 & 0.4 & 0.2 & 0.0 & 0.8 & 0.1 & 1.6 \\
Jun & 0.5 & 2.0 & 0.8 & 0.4 & 0.3 & 2.7 & 0.0 & 6.6 \\
Jul & 1.0 & 7.3 & 4.2 & 1.0 & 0.3 & 1.5 & 0.1 & 15.2 \\
Aug. & 0.9 & 7.0 & 3.6 & 1.1 & 0.9 & 3.3 & 0.1 & 16.7 \\
Sep. & 1.2 & 15.0 & 7.9 & 2.6 & 1.3 & 4.3 & 0.3 & 32.7 \\
Oct. & 0.5 & 7.9 & 8.5 & 11.4 & 0.7 & 4.5 & 0.6 & 34.0 \\
Nov. & 0.7 & 19.8 & 11.4 & 4.0 & 1.6 & 3.9 & 0.7 & 42.1 \\
Dec. & 0.7 & 22.0 & 9.0 & 3.4 & 1.1 & 2.8 & 0.4 & 39.3 \\
Jan. & 0.2 & 5.2 & 1.6 & 0.4 & 0.1 & 1.9 & 0.1 & 9.2 \\
Feb. & 0.0 & 0.2 & 0.1 & 0.0 & 0.0 & 0.2 & 0.0 & 0.4 \\
\hline Total & 5.5 & 86.6 & 47.4 & 24.3 & 6.1 & 27.0 & 2.1 & 199.0 \\
\hline \multirow{2}{*}{ Mean } & $0.5 \pm$ & $7.2 \pm$ & $3.9 \pm$ & $2.0 \pm$ & $0.5 \pm$ & $2.2 \pm$ & $0.2 \pm$ & $16.6 \pm$ \\
& 0.4 & 7.8 & 4.2 & 3.3 & 0.6 & 1.6 & 0.2 & 16.2 \\
\hline
\end{tabular}

From the obtained results presented in Table (1\&2) the striped mealybug $F$. virgata highest mean number of insect population was recorded in Sep. with mean number of insects 93.5 individuals/ sample through $1^{\text {st }}$ year of investigation. While the highest mean number of insect population was recorded late about two months in Nov. with mean number of insects 42.1 individuals/ sample through $2^{\text {nd }}$ year of investigation. The general mean number of insects per sample was higher in the $1^{\text {st }}$ year than in the $2^{\text {nd }}$ one. The mean numbers of insects were 24.7 and 16.6 individuals/ sample in the two successive years, respectively. The result is in agreement with that obtained by Ammar et al. (1979) reported that F. virgata had Three generations a year were in early June, early July and early August, and the population size increased with each generation. $F$. virgata overwintered between January and early June, probably as the adult female, in the cracks and junctions of trunks and large branches and on fallen leaves. In the laboratory, females migrated to the soil in winter. Lapis (1970) found that the $F$. virgata (Ckll.), a major pest of several vegetables and ornamental plants was investigated in the Philippines. It was most abundant from February to May and observed feeding on 76 species of plants belonging to 33 families. Nada (1987) mentioned that the degree of infestation $F$. virgate varied considerably with time of year in Egypt.

These results agree with those reported by Dawood (1 971), who studied the abundance of $F$. virgata on Dahlia plants in Egypt. The overwintering of active forms, particularly young nymphs, has been reported earlier by 
Highland (1956) in Maryland (U.S.A.), and by Rawat and Modi (1979) in Madras (India). However, Brettlje (1966) reported that in Aden, $F$. virgata can achieve quite high populations in winter, on such ornamental plants as Caesalpinia and Cleander. Highland (1956) reported that overwintering in this pseudococcid started in the second or third nymphal stage, but added that attempts to determine the exact overwintering stage failed because of parasitization.

Seasonal distribution of $F$. virgata on the ornamental corn shrubs:

In the first year the data in Table (3) cleared that the mean numbers of the insect population was highest in Autumn (64.3 individuals/ sample) with daily maximum, daily range, daily minimum of temperature and daily mean of relative humidity $21.6^{\circ} \mathrm{C}, 9.5^{\circ} \mathrm{C} 18.0^{\circ} \mathrm{C}$ and $51.7 \%$, respectively. Whereas the lowest mean number of the insect was in spring (2.7 individuals/ sample) with daily maximum, daily range, daily minimum of temperature and daily mean of relative humidity $28.3^{\circ} \mathrm{C}, 11.2^{\circ} \mathrm{C} 17.2^{\circ} \mathrm{C}$ and $45.2 \%$, respectively.

Table 3. Seasonal average numbers of $F$. virgata stages per 5 leaves of the ornamental corn shrubs during the two successive years $(2014 / 15$ and 2015/16) at Al-Zohria gardens-Cairo Governorate.

\begin{tabular}{|c|c|c|c|c|c|c|}
\hline \multirow{6}{*}{$2014 / 2015$} & \multirow[t]{2}{*}{ Season } & \multirow{2}{*}{$\begin{array}{c}\text { insects } \\
5 \\
\text { leaves }\end{array}$} & \multicolumn{3}{|c|}{ Temp. $\left({ }^{\circ} \mathrm{C}\right)$} & \multirow{2}{*}{$\begin{array}{c}\begin{array}{c}\text { Humidity } \\
\text { (\%) }\end{array} \\
\text { Mean } \\
\end{array}$} \\
\hline & & & Max. & Range & Min. & \\
\hline & Spring & 2.7 & 28.3 & 11.2 & 17.2 & 45.2 \\
\hline & Summer & 31.7 & 34.7 & 11.0 & 23.6 & 50.6 \\
\hline & Autumn & 64.3 & 27.6 & 9.5 & 18.0 & 51.7 \\
\hline & Winter & 5.3 & 18.5 & 8.2 & 10.3 & 49.4 \\
\hline \multirow{4}{*}{$2015 / 2016$} & Spring & 1.5 & 27.5 & 11.4 & 16.0 & 47.9 \\
\hline & Summer & 15.8 & 34.9 & 10.7 & 24.2 & 51.1 \\
\hline & Autumn & 44.6 & 27.9 & 9.7 & 18.2 & 55.9 \\
\hline & Winter & 7.6 & 18.7 & 9.1 & 9.6 & 52.5 \\
\hline
\end{tabular}

The summer and winter seasons had moderate mean numbers of the insect population (31.7 and 5.3 individuals/ sample) with daily maximum, daily range, daily minimum of temperature and daily mean of relative humidity $34.7^{\circ} \mathrm{C}, 11.0^{\circ} \mathrm{C} 23.6^{\circ} \mathrm{C}$ and $50.6 \%$ respectively in summer and $18.5^{\circ} \mathrm{C}, 8.2^{\circ} \mathrm{C} 10.3^{\circ} \mathrm{C}$ and $49.4 \%$ respectively in winter.

In the second year the data in Table (3) cleared that the same trend as in 2014/2015, the mean numbers of the insect population was highest in autumn (44.6 individuals/ sample) with daily maximum, daily range, daily minimum of temperature and daily mean of relative humidity $27.9^{\circ} \mathrm{C}$, $9.7^{\circ} \mathrm{C} 18.2^{\circ} \mathrm{C}$ and $55.9 \%$ respectively. Whereas the lowest mean number of the insect was in spring (1.5 individuals/ sample) with daily maximum, daily range, daily minimum of temperature and daily mean of relative humidity $27.5^{\circ} \mathrm{C}$, $11.4^{\circ} \mathrm{C} 16.0^{\circ} \mathrm{C}$ and $47.9 \%$ respectively. The summer and winter seasons showed a moderate mean numbers of the insect population (15.8 and 7.6 individuals/ sample) with daily maximum, daily range, daily minimum of temperature and daily mean of relative humidity $34.9,10.7$, 24.2 and $51.1 \%$ in summer and 18.7, 9.1, 9.6 and $52.5 \%$ in winter, respectively. The data was in agreement with Ammar et al. (1979) reported that three distinct generations in density of mealybug $F$. virgata are observed during the summer and fall seasons and overwintered between January and early June.

The preferable direction of $F$. virgata on the ornamental corn shrubs:

The results obtained for 2014/2015 are graphically illustrated in Fig (1). The data showed significant differences among the mean numbers of F.virgata at the four cardinal directions. Eastern leaves of $D$. fragrans harbored the highest mean number of $F$. virgata and consisted the first group with 42.8 individuals/ sample. The other three directions harbored less numbers and had insignificant differences among their means which formed anther group with mean numbers of $25.8,29.1$ and 21.7 individuals/ sample for western, northern and southern directions, respectively. The preferred direction of the whole data of 2014/2015 year could be found in north-eastern of the $D$. fragrans plant with an angle of $23.5^{\circ}$ to the east Fig. (2).

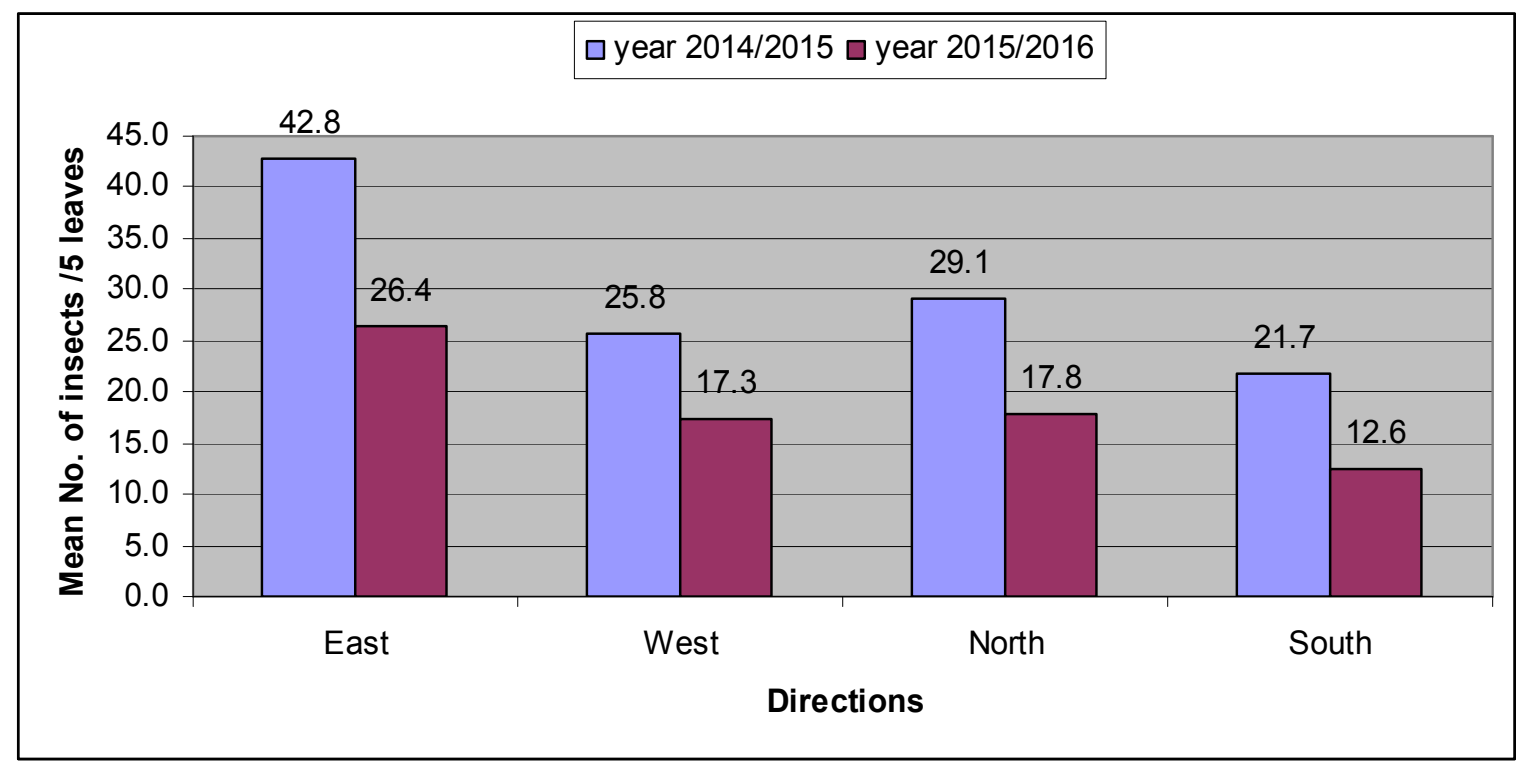

Fig. 1. The mean numbers of $F$. vergata stages per 5 leaves at different cardinal directions on $D$. fragrans during 2014 /2015 and 2015/2016 years at Al-Zohria Garden-Cairo Governorate. 


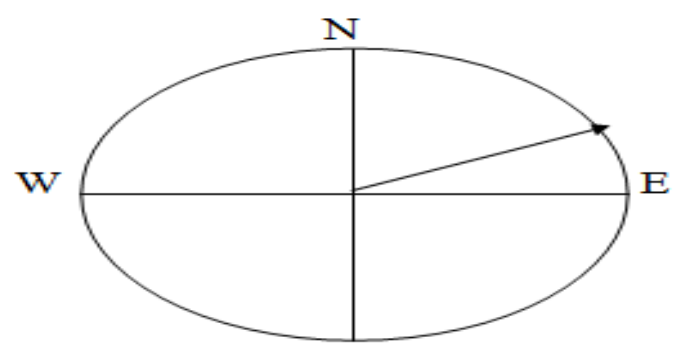

$\mathrm{S}$

Angle $=23.5^{\circ}$

First season 2014/ 2015

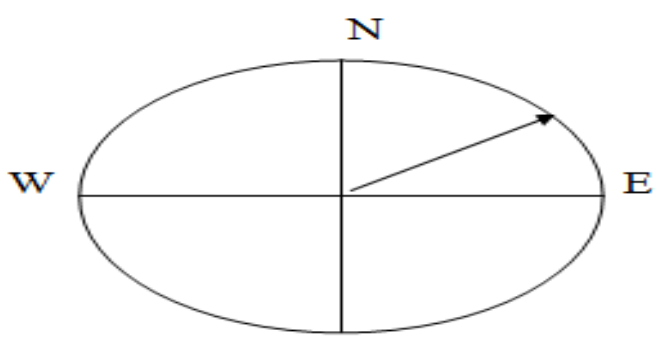

$\mathrm{S}$

\section{Second season 2015/2016}

Fig. 2. Preferable cardinal direction of $F$. virgata mealybug infestation on $D$. fragrans at Al-Zohria gardens, Cairo, Egypt during the two years (2014/2015 \& 2015/2016).

Data obtained during year $2015 / 2016$ illustrated in Fig (1) showed the same trend as in 2014/2015. The data showed that differences among the means of $F$. virgata mean numbers were significant. D. fragrans plants at eastern direction harbored the highest $F$. virgata mean numbers forming one separate group followed by the mean numbers of $F$. virgata at Northern, western and southern directions forming two overlapping groups. Mean numbers of the insect throughout the whole year were 26.4, 17.8, 17.3 and 12.6 per sample for the four directions eastern, northern, western and southern, respectively. The preferred direction of the whole data during year 2015/2016 could be found in north-eastern of the $D$. fragrans plant with an angle of $29.7^{\circ}$ to the east Fig. (2).

From the above mentioned results, it could be concluded that the highest number of $F$. virgata was mostly accumulated at the north eastern direction of $D$. fragrans these results may be attributed to the wind direction which always flow from north to west direction and drift $F$. virgata population towards the opposite direction. The data not was in agreement with the finding of Ammar, et.al. (1979) in which they found the preferred cardinal directions for distribution of the $F$. virgata southeast in the first generation and south-west in the second and third generations on Acalypha shrubs at Giza region.

Effect of biotic and abiotic factors on the population activities of $F$. virgata on the ornamental corn shrubs:

The obtained results presented in Tables $(4 \& 5)$ showed the relations between a biotic factors, (the daily maximum, range, minimum of temperature and the daily mean of relative humidity, one week before inspection) and biotic factor (natural enemies) and the population activity of F.virgata. These factors played different roles in the population fluctuations of the insect pest during the two successive years (2014/2015 and 2015/2016).

In the first year (2014/2015):

(A) Effect of daily mean maximum of temperature:

Table (4) gives simple correlation (r) and regression (b) values for mean number of $F$. virgata and daily maximum of temperature. Simple correlation was insignificant positive in spring $(\mathrm{r} .=0.315)$ and autumn $(\mathrm{r}=$ 0.056).

While the relation was insignificant negative in summer $(r .=-0.365)$ and winter $(r=-0.056)$.

\section{B) Effect of daily rang of temperature:}

The relation between daily range of temperature and population activity of $F$. virgata was highly significant positive correlation $(\mathrm{r} .=0.737)$ in summer while in spring it was insignificant positive $(\mathrm{r} .=0.065)$. This relation was insignificant negative in autumn $(\mathrm{r} .=-0.151)$ and winter $(\mathrm{r}$ $=-0.256$ ), Table (4).

Table 4. Simple correlation coefficient, partial regression values and explained variance (E.V.) between tested weather factors, natural enemies and population activity of mealybug, $F$. virgata on the ornamental corn shrubs during 2014/2015 year, at Al-zohria gardens.

\begin{tabular}{|c|c|c|c|c|c|c|c|}
\hline \multirow[t]{2}{*}{ seasons } & \multirow[t]{2}{*}{ Factors } & \multicolumn{2}{|c|}{$\begin{array}{c}\text { Simple } \\
\text { correlation }\end{array}$} & \multicolumn{2}{|c|}{$\begin{array}{c}\text { Partial } \\
\text { regression } \\
\text { analysis }\end{array}$} & \multirow{2}{*}{\multicolumn{2}{|c|}{$\begin{array}{c}\text { Prob E.V. } \\
>\text { F }\end{array}$}} \\
\hline & & r. & P. & b. & p. & & \\
\hline \multirow{5}{*}{ Spring } & T. max & 0.315 & 0.234 & -1.406 & 0.1331 .220 & 0.358 & 30.60 \\
\hline & T. rang & 0.065 & 0.810 & 1.407 & 0.137 & & \\
\hline & T. mini & 0.366 & 0.164 & 1.426 & 0.128 & & \\
\hline & R.H \% & -0.183 & 0.498 & 0.001 & 0.931 & & \\
\hline & $\begin{array}{c}\text { Nat. } \\
\text { enemies }\end{array}$ & 0.000 & 0.000 & 0.000 & 0.000 & & \\
\hline \multirow{5}{*}{ Summer } & $\mathrm{T}$.max & -0.365 & 0.220 & -7.383 & 0.7832 .040 & 0.190 & $\overline{59.20}$ \\
\hline & T. rang & $0.737 * *$ & $=0.004$ & 5.168 & 0.848 & & \\
\hline & T. mini & 0.459 & 0.115 & 8.635 & 0.753 & & \\
\hline & R.H \% & 0.247 & 0.417 & -0.139 & 0.812 & & \\
\hline & $\begin{array}{c}\text { Nat. } \\
\text { enemies }\end{array}$ & 0.447 & 0.126 & 0.357 & 0.883 & & \\
\hline \multirow{5}{*}{ Autumn } & T. $\max$ & 0.060 & 0.846 & $\overline{-}$ & 0.5141 .970 & 0.201 & 58.40 \\
\hline & T. rang & -0.151 & 0.621 & 10.330 & 0.541 & & \\
\hline & T. mini & 0.139 & 0.652 & 11.511 & 0.505 & & \\
\hline & R.H \% & -0.047 & 0.879 & 0.029 & 0.878 & & \\
\hline & $\begin{array}{c}\text { Nat. } \\
\text { enemies }\end{array}$ & $0.669^{*}$ & 0.012 & 1.566 & 0.058 & & \\
\hline \multirow{5}{*}{ Winter } & T. $\max$ & -0.056 & 0.878 & $\begin{array}{c}- \\
24.884\end{array}$ & 0.1656 .740 & 0.044 & 89.40 \\
\hline & T. rang & -0.256 & 0.475 & 24.103 & 0.176 & & \\
\hline & T. mini & 0.133 & 0.715 & 26.581 & 0.147 & & \\
\hline & R.H \% & 0.317 & 0.371 & 0.060 & 0.553 & & \\
\hline & $\begin{array}{c}\text { Nat. } \\
\text { enemies }\end{array}$ & $0.739^{*}$ & 0.015 & 2.387 & 0.013 & & \\
\hline
\end{tabular}


C) Effect of daily mean minimum of temperature:

The relation between daily mean minimum of temperature and population activity of $F$. virgata was insignificant positive in the four seasons $\mathrm{r}=0.366,0.459$, 0.139 and 0.133 , respectively, Table (4).

D) Effect of daily mean relative humidity:

The relation between R.H\% and population activity of $F$. virgata was insignificant positive in the winter and summer $(\mathrm{r} .=0.317)$ and $(\mathrm{r} .=0.247)$ respectively. In the other hand this relation in the spring and autumn was insignificant but negative (r. $=-0.183)$ and $(\mathrm{r} .=-0.047)$ respectively, Table (4).

E) Effect of the natural enemies:

Table (4) showed that the relation between natural enemies and population activity of $F$. virgata is not founded in the spring season because the natural enemies was not observed, but in the summer, autumn and winter seasons the relation was insignificant positive in summer (r. $=0.447)$, but it was significant positive in autumn and winter $(\mathrm{r} .=0.669)$ and $(\mathrm{r} .=0.739)$ respectively, Table (4).

F) The combined effects of biotic and abiotic factors on the population activities of $F$. virgata on the ornamental corn shrubs:

As mention ed in Table (4), the partial regression method was adopted in this study. The partial regression values indicate that the average rate of change in the activity due to a unit change in any of the factors. The estimated partial regression values indicate the presence of simultaneous effect of these factors on the population of insect. These values were insignificant in the spring, summer and autumn, while it was significant in the winter. The responsibility of all factors combined, expressed as amount of percentage of explained variance were 30.6, 59.2, 58.4 and 89.4 in the spring, summer, autumn and winter respectively during 2014-2015.

In the second year (2015 / 2016):

(A)Effect of daily maximum of temperature:

Table (5) gives simple correlation ( $\mathrm{r}$ ) and regression (b) values for population activity of $F$. virgata and daily maximum of temperature. The $(\mathrm{r})$ values was insignificant positive in the spring and the summer $(\mathrm{r} .=0.401)$ and $(\mathrm{r} .=$ 0.172 ), respectively. While the relation was significant negative in the autumn $(\mathrm{r} .=-0.650)$. In the other hand the relation between maximum temperature and population activity of $F$. virgata had insignificant and negative relation $(\mathrm{r} .=-0.036)$ in the winter.

B) Effect of daily rang of temperature:

The relation between daily range of temperature and population activity of $F$. virgata was insignificant and positive relation $(r .=0.166)$ in spring while in summer, autumn and winter was insignificant but negative r. = $0.380,-0.394$ and -0.009 , respectively, Table (5).

C) Effect of daily minimum of temperature:

The relation between daily minimum of temperature and population activity of $F$. virgata was insignificant positive in the spring and summer $(\mathrm{r} .=0.429)$ and $(r .=0.400)$ respectively. While in autumn this relation was significant negative $(r .=-0.595)$ but in the winter the relation had insignificant and negative relation (r. $=$ 0.050) Table (5).
D) Effect of daily mean relative humidity:

Table (5) indicated that the relation between R.H\% and population activity of $F$. virgata was insignificant positive in the spring and autumn (r. $=0.373)$ and (r. $=$ $0.499)$ respectively while it was highly significant negative in the winter $(\mathrm{r} .=-0.823)$. In the other hand the relation in the summer was insignificant negative $(r .=-0.006)$.

E) Effect of the natural enemies:

The relation between natural enemies and population activity of $F$. virgata was insignificant positive in all seasons spring, summer, autumn and winter $\mathrm{r}$. $=$ $0.468, \mathrm{r} .=0.401, \quad \mathrm{r} .=0.407$ and $\mathrm{r} .=0.210$ respectively, Table(5).

Table 5. Simple correlation coefficient, partial regression values and explained variance (E.V.) between tested weather factors, natural enemies and population activities of mealybug, $F$. virgaat on the ornamental corn shrubs during year 2015/2016 year at Al-Zohria gardens

\begin{tabular}{|c|c|c|c|c|c|c|c|}
\hline \multirow[t]{2}{*}{ Seasons } & \multirow[t]{2}{*}{ Factors } & \multicolumn{2}{|c|}{$\begin{array}{c}\text { Simple } \\
\text { correlation }\end{array}$} & \multicolumn{2}{|c|}{$\begin{array}{c}\text { Partial } \\
\text { regression } \\
\text { analysis }\end{array}$} & \multirow[t]{2}{*}{ "F" } & \multirow[t]{2}{*}{$\begin{array}{c}\text { Prob E.V. } \\
>\text { F }\end{array}$} \\
\hline & & r. & P. & b. & p. & & \\
\hline \multirow{5}{*}{ Spring } & T.max & 0.401 & 0.124 & 1.917 & 0.242 & \multirow[t]{5}{*}{7.640} & \multirow[t]{5}{*}{0.00379 .20} \\
\hline & T.rang & 0.166 & 0.538 & -1.867 & 0.253 & & \\
\hline & T.mini & 0.429 & 0.098 & -1.841 & 0.261 & & \\
\hline & \multirow{2}{*}{$\begin{array}{c}\text { R.H \% } \\
\text { Nat. } \\
\text { enemies }\end{array}$} & 0.373 & 0.155 & 0.049 & 0.009 & & \\
\hline & & 0.468 & 0.068 & 0.292 & 0.024 & & \\
\hline \multirow{5}{*}{ Summer } & T.max & 0.172 & 0.575 & -3.753 & 0.420 & \multirow{5}{*}{1.630} & \multirow[t]{5}{*}{0.26853 .80} \\
\hline & T.rang & -0.380 & 0.200 & 3.398 & 0.460 & & \\
\hline & T.mini & 0.400 & 0.176 & 3.976 & 0.393 & & \\
\hline & \multirow{2}{*}{$\begin{array}{l}\text { R.H \% } \\
\text { Nat. } \\
\text { enemies }\end{array}$} & -0.006 & 0.985 & 0.024 & 0.727 & & \\
\hline & & 0.401 & 0.175 & 0.751 & 0.112 & & \\
\hline \multirow{5}{*}{ Autumn } & T.max & $-0.650^{*}$ & 0.022 & 41.626 & 0.371 & \multirow[t]{5}{*}{1.460} & \multirow[t]{5}{*}{0.32654 .93} \\
\hline & T.rang & -0.394 & 0.206 & -42.917 & 70.348 & & \\
\hline & T.mini & $-0.595^{*}$ & 0.041 & -41.891 & 0.369 & & \\
\hline & R.H \% & 0.499 & 0.099 & 0.129 & 0.729 & & \\
\hline & $\begin{array}{c}\text { Nat. } \\
\text { enemies }\end{array}$ & 0.407 & 0.189 & 0.466 & 0.779 & & \\
\hline \multirow{5}{*}{ Winter } & T.max & -0.036 & 0.922 & 0.048 & 0.546 & \multirow[t]{5}{*}{10.960} & \multirow[t]{5}{*}{0.00687 .96} \\
\hline & T.rang & -0.009 & 0.980 & -0.553 & 0.262 & & \\
\hline & T.mini & -0.050 & 0.890 & 0.020 & 0.300 & & \\
\hline & R.H \% & $-0.823^{*}$ & $=0.003$ & 0.374 & 0.170 & & \\
\hline & $\begin{array}{c}\text { Nat. } \\
\text { enemies }\end{array}$ & 0.210 & 0.182 & 0.711 & 0.004 & & \\
\hline
\end{tabular}

Numbers followed by (*) are significant differences and number followed by $(* *)$ are highly significant differences

F) The combined effects of biotic and abiotic factors on the population activities of $F$. virgata on the ornamental corn shrubs:

These values were insignificant in the summer and autumn but highly significant in the spring and winter. The responsibility of all factors combined, expressed as amount of percentage of explained variance were 79.20, 53.80, 54.93 and 87.96 in the spring, summer, autumn and winter respectively.

The data were in agreement to Ammar et al,. (1979) they showed that significant positive correlation found between population density of $F$. virgata and daily maximum and minimum temperatures, but not between population density and relative humidity. And Assem (1982) showed the relationship between the population 
activity of $M$. hirsutus and weather factors, the minimum temperature was insignificantly positive during the fall, spring and summer and disagreement with the maximum daily temperature it was significantly positive during spring, while it gave a positive insignificant correlation during the fall and summer. On the other hand, the relative humidity gave an insignificant positive effect during the fall, winter and summer. Many authors showed the same effects of meteorological parameters on the population activities of mealybugs, Nabil, et al, (2013) and Raut, et al, (2013).

\section{REFERENCES}

Ammar, E. D. Awadallah, K. T. Rashad, A. (1979) Ecological studies on Ferrisia virgata Ckll. on Acalypha shrubs in Dokki, Giza (Homoptera, Pseudococcidae). Deutsche Entomologische Zeitschrift; 26(4/5):207-213.

Assem, S. M.(1982) Studies on certain coccid pests of ornamental plants in Egypt M. Sc. Thesis, faculty of agric., Ain Shams University, Egypt, 160 pp.

Bazarov, B. B. (1988). The grape mealybug. ZashchitaRastenii- Moskva, (8): 29-30.

Beardsley, J.W.(1977) Some thought on mealybug and mealybug management. Proceedings of the international workshop on Phenacoccus manihoti MAT FERR pg 65-69.

Brettelje. ,H . (1966): Eleven years work in Abyan (South Arabia) by entomologists of the Empire Cotton Growing Corporation. - Emp. Cott. Grow. Rev., 43: 286-295.

Dawood M,. Z. (1971): Survey of Aphids and Mealy-Bugs infesting ornamental Plants. - M. SC. Thesis, Facul. Agric. Cairo Univer., 114 pp.

Duncan, B.B. (1955): Multiple range and multiple F test Biometrics 11: 1-32.

Gaaboub, I.A., Rawash, I.A., Abdel-lattif, M. A., ELMinshawy, A. and abdel-Rahman, A.M., (1979) Biological studies and effect of treatment with two juvenile hormone mimics on the developmental stages of Icerya purchase (Mask) and Planococcus citri (Risso). Medelingen van de fackulteit landbowwetenschappen, Rijksuniversiteit Gent, 44:185203.
Highland,. A. (1956): The Biology of Ferrisiana virgata, a pest of Azaleas. - J. econ. Ent., 49: 276-277.

Keena, M. A. (2006). Effects of temperature on Anoplophora glabripenis (Coleoptera: Cerambycidae) adult survival, reproduction, and egg hatch. Environ. Entomol. 35, 912- 921.

Lapis, E. B.(1970) The biology of the grey mealybug, Ferrisia virgata (Cockerell) (Pseudococcidae, Homoptera). Philippine Entomologist; 1(5):397405.

Mangala, N.; Sundararaj, R.; Nagaveni, H. C (2012). Scales and mealybugs (Coccoidea: Hemiptera) infesting Pongamia pinnata (L.) Pierre and their population dynamics in Karnataka, India. Annals of Forestry, 20(1):110-116.

Nabil, Dalia Z.; Amin, A. H.; Abdallah, Y. E. Y and Nagwa A. Hassan (2013) Certain ecological aspects for Icerya seychellarum (Westwood) on coffee plants Coffea arabica in Egypt. J. Plant Prot. and Path., Mansoura Univ., Vol. 4 (3): 265 - 277.

Nada, S. M. A. (1987). Common coccid pests on ornamental plants in some greenhouses of Egypt. Bulletin de la Societe Entomologique d'Egypte; (66):167-168

Raut, A. P.; Kulkarni, S. R.; Patil, S. K.(2013). Seasonal incidence of mealybug on custard apple (Annona squamosa L.) in relation to weather parameters. Journal of Agriculture Research and Technology; 2013. 38(3):502-504.

Rawat, R. R. Modi, B. N.(1979) Studies on biology of Ferrisia virgata Ckll. (Pseudococcidae: Homoptera) in Madhya Pradesh. Indian Journal of Agricultural Sciences.; 1969. 39(3):274-281.

SAS Institute, 1988. SAS User Guide Statistical Cary, N.USA.

\section{كثافة التعداد لمجاميع البق الاقيقى المخطط على نبات الزينة (دراسينا ذرة) وعلاقة ذلك بالعوامل الحيوية وغير الحيوية

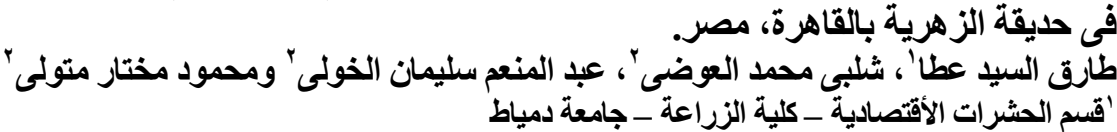

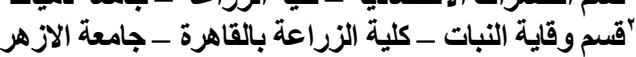

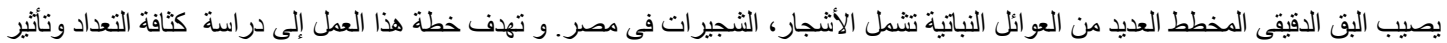

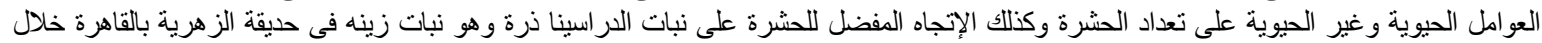

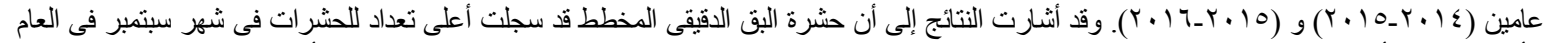

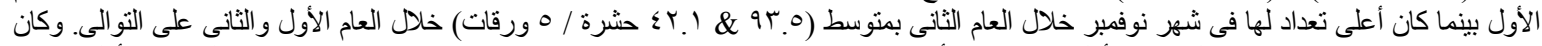

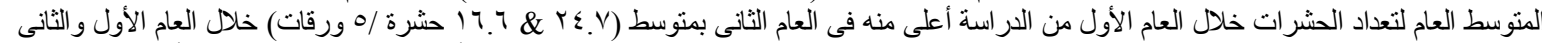

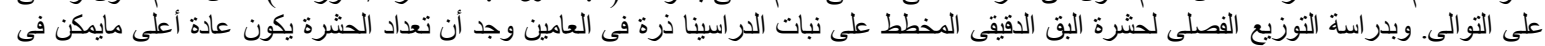

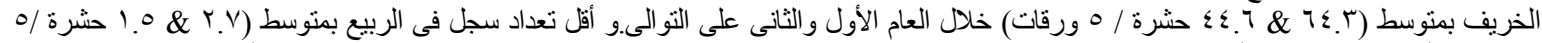

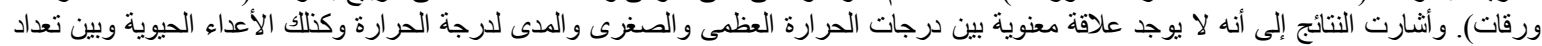

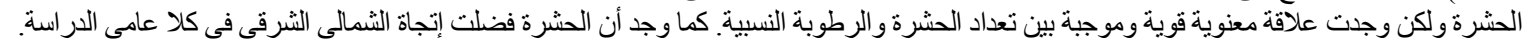

